\title{
Pemberian Alat Pengemasan dan Pelatihan Peningkatan Kualitas Makanan Khas Geti di Desa Purwosari Kabupaten Wonogiri
}

\author{
Nurafidah $^{1)}$, Tegar Rezki Pangestu ${ }^{2}$, Kris Suryowati ${ }^{3)}$, Rokhana Dwi Bekti ${ }^{4)}$ \\ 1,2,3,4 Jurusan Statistika, Fakultas Sains Terapan, Institut Sains \& Teknologi AKPRIND Yogyakarta \\ Email: nurafidah.fidah@yahoo.com ${ }^{1}$, thegarreskipangestu@ gmail.com ${ }^{2}$, suryowati@akprind.ac.id $^{3}$, \\ *rokhana@akprind.ac.id ${ }^{4}$
}

Cara Mensitasi Artikel ini:

Nurafidah, N., Pangestu, T. R., Suryowati, K., \& Bekti, R. D. (2021). Pemberian alat pengemasan dan pelatihan peningkatan kualitas makanan khas geti di Desa Purwosari Kabupaten Wonogiri. ABDIMASY: Jurnal Pengabdian dan Pemberdayaan Masyarakat, 2(2), 60-67. https://doi.org/10.46963/ams.v2i2.417

\section{DOI}

https://doi.org/10.46963/ams.v2i2 $\underline{.417}$

\section{Sejarah Artikel}

$\begin{array}{ll}\text { Diterima } & : 08 / 11 / 2021 \\ \text { Direvisi } & : 14 / 12 / 2021 \\ \text { Diterbitkan } & : 31 / 12 / 2021\end{array}$

*) Corresponding Author rokhana2@akprind.ac.id

\section{Editorial Address}

Kampus Panam (Parit Enam) STAI Auliaurrasyidin, Jl. Gerilya No. 12 Tembilahan Barat, Riau, Indonesia, 29213 abdimasy@stai-tbh.ac.id

\section{Kata Kunci:}

Alat Pengemasan, Pelatihan, Geti

Keywords:

Packaging Equipment, Training, Geti
Abstract: There are so many types of traditional food in Indonesia that have a unique taste and characterize the local culture. However, nowadays many traditional specialties are still unable to compete with modern foods such as Geti Wijen. Some of the things that cause it are promotions that have not been widely used in various media and the appearance of packaging that is less attractive. One of the geti wijen businesses is Geti Mrs. Atmo in Dusun Geneng, Purwosari, Wonogieri District. This business has an unattractive packaging because the packaging process still uses simple tools and materials, namely plastic and wax. Therefore, the team provided a packaging tool assistance program and usage training to improve packaging quality. Implementation methods include planning activities, providing tools, implementing training, and evaluating programs. This program has provided many benefits for Mrs. Atmo in improving the quality of products that are able to compete in the market. Partners have packaging tools and attractive packaging designs so that the packaging process is faster.

Abstrak: Banyak sekali jenis makanan tradisional di Indonesia yang memiliki citra rasa unik dan mencirikan budaya daerah. Namun demikian, saat ini makanan khas tradisional masih banyak yang kalah bersaing dengan makanan modern seperti geti wijen. Beberapa hal yang menyebabkannya adalah promosi yang belum luas di berbagai media serta tampilan kemasan yang kurang menarik. Salah satu usaha geti wijen adalah Geti Bu Atmo di Dusun Geneng, Desa Purwosari, Kecamatan Wonogieri, Kabupaten Wonogiri. Usaha ini memiliki kemasan yang kurang menarik karena proses pengemasan masih menggunakan alat dan bahan yang sederhana, yaitu plastik dan lilin. Oleh karena itu tim memberikan program bantuan alat pengemasan dan pelatihan penggunaan untuk meningkatkan kualitas kemasan. Metode pelaksanaan diantaranya perencanaan kegiatan, pemberian alat, pelaksanaan pelatihan dan evaluasi program. Program ini telah memberikan banyak manfaat untuk geti Bu Atmo dalam meningkatkan kualitas produk yang mampu bersaing di pasar. Mitra memiliki alat pengemas dan desain kemasan yang menarik sehingga proses pengemasan lebih cepat. 


\section{PENDAHULUAN}

Geti adalah salah satu makanan khas Wonogiri yang terbuat dari kacang tanah, wijen, ataupun gabungan dari keduanya. Makanan khas ini menjadi salah satu produk andalan di Desa Purwosari, Kecamatan Wonogiri, Kabupaten Wonogiri. Namun demikian, makanan ini masih kalah bersaing dengan produk kuliner lain yang lebih modern sehingga peminatnya relatif kecil dan belum luas.

Salah satu tempat pembuatan geti di Desa Purwosari adalah Geti Wijen Bu Atmo di Dusun Geneng. Pembuatan geti ini masih skala rumah tangga. Selain itu, hanya dilakukan saat ada pesanan, hal ini dikarenakan minat masyarakat terhadap geti sudah tidak sebanyak dulu. Pembuatan geti ini pun masih sangat sederhana baik dari segi alat pembuatan yang sangat minim maupun kemasan geti yang hanya menggunakan plastik tipis dan lilin sebagai penutup plastik, dari segi penjualan pun masih secara konvensional di mana hanya dapat dipesan dengan pemesanan langsung ke tempat pembuatan. Padahal jika dikerjakan dengan alat yang lebih baik, kemasan yang lebih menarik, dan sarana penjualan yang lebih modern maka penjualan geti ini dapat meningkat.

Beberapa upaya telah dilakukan untuk membantu meningkatkan kualitas produk Geti di berbagai wilayah di Indonesia. Salah satunya oleh Rachmawati (2018:1) yang menerapkan proses quality control di Geti "Pak Kino" Dusun Geneng, Wonogiri untuk mengetahui pengendalian kualitas pada proses pembuatan geti wijen dari bahan baku, proses produksi dan produk akhir.
Triachdiani and Murtini (2021:100) melakukan analisis pengaruh varietas kacang tanah dan rasio gula aren-gula pasir terhadap karakteristik enting-enting geti. A'Yunin (2018:12) melakukan analisis strategi pemasaran produk geti di Tulungangung dalam upaya menjaga loyalitas konsumen.

Pandemi Covid-19 telah memberikan dampak besar pada berbagai bidang sehingga perlu banyak program yang dapat membantu masyarakat untuk beradaptasi dengan kebiasaan baru. Tim telah mengadakan beberapa kegiatan pengabdian diantaranya memberikan sosialisasi dan bantuan pencegahan Covid-19 di Malangan Kota Yogyakarta (Bekti, Suryowati, \& Suseno, 2020a:99), program pengelolaan sampah (Suryowati, Suseno, \& Bekti, 2020:363), dan program penanaman sayuran (Bekti, Suryowati, \& Suseno, 2020b:310).

\section{Pandemi Covid-19 sangat} memberikan dampak pada kehidupan ekonomi khususnya pasar Geti maupun makanan tradisional lain. Suprayitno, Lukito, dan Farida (2021:49) melakukan analisis rekonstruksi dampak ekonomi UMKM Kabupaten Blitar di tengah Covid-19. Beberapa dampak yang dialami UMKM Geti adalah beberapa tempat wisata tutup sehingga pembeli juga menurun. Sunarsasi dan Hartono (2020:22) menganalisis strategi pemasaran usaha kecil menengah UKM Cap Kuda Terbang Bu Sulasmi yang memproduksi Geti di Kabupaten Blitar. Para pelaku usaha jenis kuliner tradisional harus mampu mengembangkan strategi pemasaran, mulai dari menerapkan pemasaran via 
media sosial dan Marketplace. Selain itu bentuk tampilan kemasan juga harus lebih modern.

Langkah peningkatan kualitas produk dan pasar produk Geti Bu Atmo juga sangat diperlukan. Oleh karena itu tim memberikan alat pengemasan produk. Selanjutnya juga melakukan pelatihan penggunaan alat hingga menghasilkan kemasan yang menarik untuk meningkatkan penjualan.

\section{METODE}

Tim pelaksana terdiri dari dosen dan mahasiswa di Jurusan Statistika, Fakultas Sains Terapan, Institut Sains \& Teknologi AKPRIND Yogyakarta. Kegiatan dilaksanakan pada SeptemberOktober 2021 di produksi Geti Bu Atmo, Dusun Geneng, Desa Purwosari, Kec Wonogiri, Kabupaten Wonogiri. Kegiatan ini juga merupakan rangkaian dari kegiatan Proposal Program Holistik Pembinaan dan Pemberdayaan Desa (PHP2D) pendanaan Kemdikbud tahun 2021 dan KKNT MBKM.

Tahapan-tahapan kegiatan meliputi persiapan, sosialisasi, pelaksanaan, hingga evaluasi. Persiapan dimulai dengan perumusan permasalahan mitra dan persiapan alat. Sosialisasi dilakukan dengan menemui Kepala Desa mengunjungi tempat mitra terkait tujuan kegiatan dan koordinasi pelaksanaannya. Pelaksanaan meliputi pelatihan dan penyerahan alat pengemasan produk, dan evaluasi. Seluruh tahapan dilakukan sesuai protokol kesehatan dalam pencegahan Covid-19, di mana tidak ada kerumunan warga dalam jumlah banyak dan menggunakan langkah pencegahan penularannya.

\section{HASIL DAN PEMBAHASAN}

Makanan tradisional adalah makanan yang telah membudaya di kalangan masyarakat Indonesia, serta telah ada sejak nenek moyang suku nusantara. Geti adalah salah satu makanan khas tradisional yang terbuat dari kacang tanah, ada pula yang terbuat dari wijen ataupun gabungan dari keduanya (Gambar 1). Kacang tanah dan biji wijen di rekatkan dengan rebusan gula merah yang pekat dan kemudian dikeringkan. Rasa yang disajikan dari Geti ini manis yang berasal dari gula merah serta gurih dari kacang tanah dan biji wijen. Beberapa daerah yang memproduksi makanan ini diantaranya Kabupaten Ngawi, Kabupaten Blitar, Kabupaten Tulungagung di Provinsi Jawa Timur, Kabupaten Wonogiri di Provinsi Jawa Tengah, dan sebagainya.

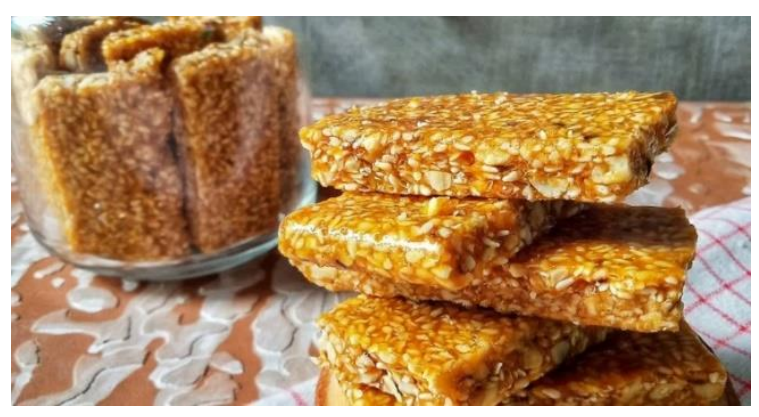

Gambar 1. Makanan khas Geti

Lokasi Geti $\mathrm{Bu}$ Atmo bertempat di Dusun Geneng Desa Purwosari Kecamatan Wonogiri Kabupaten Wonogiri. Sementara itu, Desa Purwosari berjarak sekitar $6 \mathrm{Km}$ dari Kecamatan Wonogiri dan $21 \mathrm{Km}$ dari Kabupaten Wonogiri. Desa Purwosari memiliki luas 597,42 ha dengan kepadatan penduduk $870 \mathrm{jiwa} / \mathrm{km} 2$.

Tim telah mengunjungi mitra, Geti $\mathrm{Bu}$ Atmo, pada minggu pertama April 
Pemberian alat pengemasan dan pelatihan peningkatan kualitas makanan khas geti di .........

2021. Kunjungan dilaksanakan Bersama perwakilan dari Dinas KUKM dan Perindag Kabupaten Wonogiri untuk mengetahui tentang potensi dan permasalahan Geti Bu Atmo (Gambar 1). Salah satu masalah adalah penggunaan alat sederhana dalam mengemas, yaitu hanya menggunakan plastik tipis dan lilin sebagai penutup plastik. Padahal jika dikerjakan dengan alat yang lebih baik, kemasan yang lebih menarik, dan sarana penjualan yang lebih modern maka penjualan geti ini dapat meningkat.
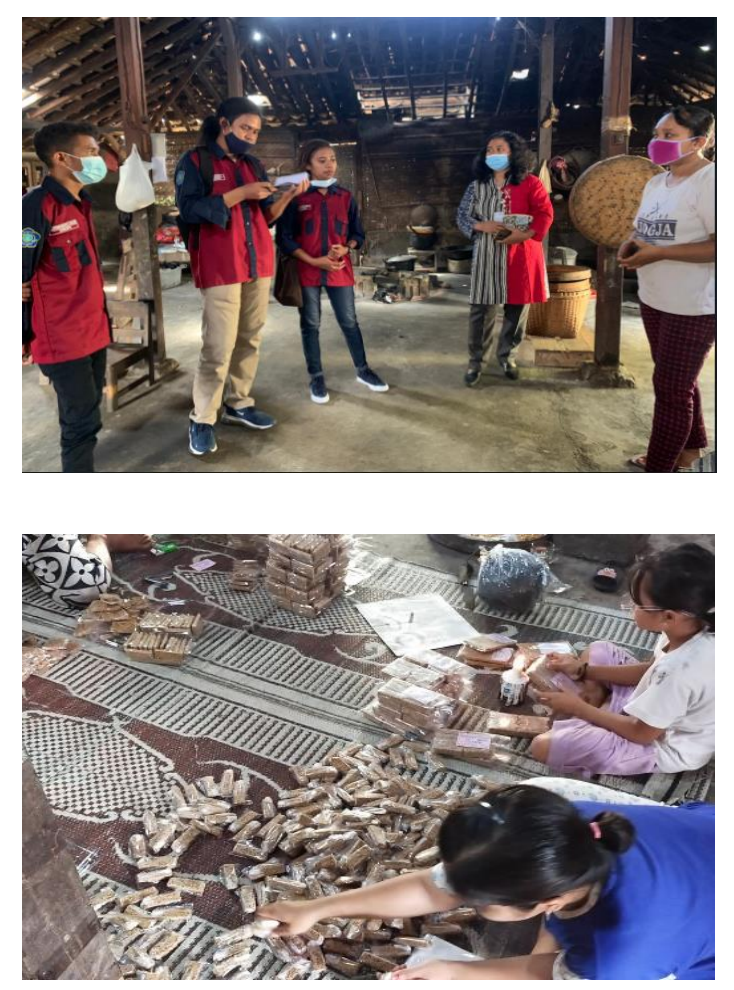

Gambar 2. Survei ke Lokasi Produksi Geti

Di Dusun Geneng terdapat 2 UMKM Geti yang masih aktif dalam memproduksi geti. Salah satunya adalah Geti Bu Atmo yang akan menjadi sasaran untuk program. Geti Bu Atmo sudah berdiri sejak 1965 dan masih tetap aktif sampai sekarang. Menurut hasil wawancara dengan pemilik usaha ini,
Geti $\mathrm{Bu}$ Atmo sudah di turunkan ke generasi ke 3. Walaupun usaha ini sudah cukup lama berdiri, tetapi untuk pemasarannya hanya dilakukan di sekitar daerah dan hanya sampai Solo saja. Untuk pemesanan geti ini hanya bisa dilakukan jika mendatangi tempat usaha secara langsung atau bisa dengan menghubungi kontak dari pemilik usaha geti tersebut yang mana ruang lingkup pasar usaha ini masih dibilang cukup kecil untuk usaha yang sudah berdiri selama kurang lebih 55 tahun ini.

Berdasarkan permasalahan pada mitra tersebut, maka tim memberikan beberapa program untuk peningkatan potensi pasar yang telah dilakukan sejak Agustus 2021. Terkait pengemasan produk, bantuan program yang diberikan adalah berupa alat pengemasan produk dan pelatihannya. Kegiatan ini dilaksanakan pada Sabtu, 16 Desember 2021 di lokasi produksi geti Bu Atmo (Gambar 2). Kegiatan dihadiri oleh karyawan Geti Bu Atmo dan perwakilan dari Dinas KUKM dan Perindag Kabupaten Wonogiri. Pemberian alat pengemasan produk bertujuan supaya proses pengemasan tidak sesederhana sebelumnya, sehingga proses proses pengemasan lebih cepat dan kemasan lebih menarik.

Tim juga memberikan desain kemasan seperti di Gambar 3. Setelah agenda penyerahan alat, selanjutnya tim memberikan pelatihan penggunaan alat pengemasan dan praktik penggunaannya (Gambar 4). Melalui pelatihan ini, mitra mampu menggunakan alat secara mandiri. 


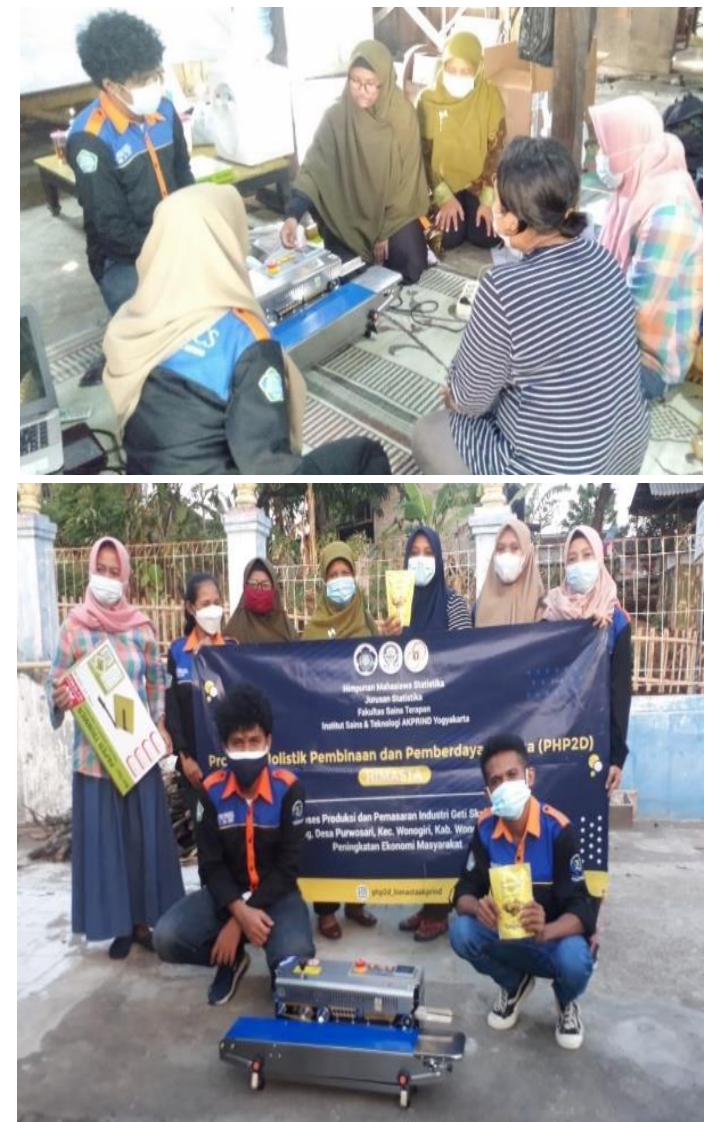

Gambar 2. Penyerahan bantuan alat pengemasan produk

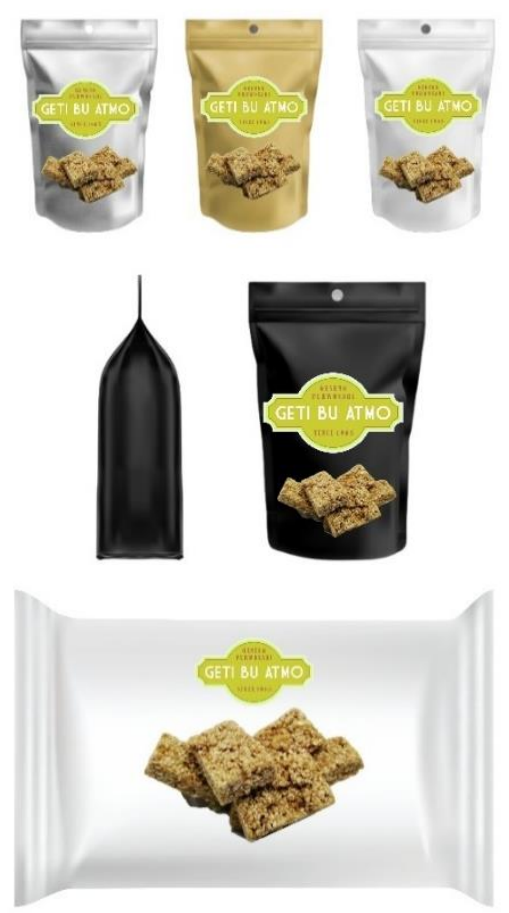

Gambar 3. Desain kemasan
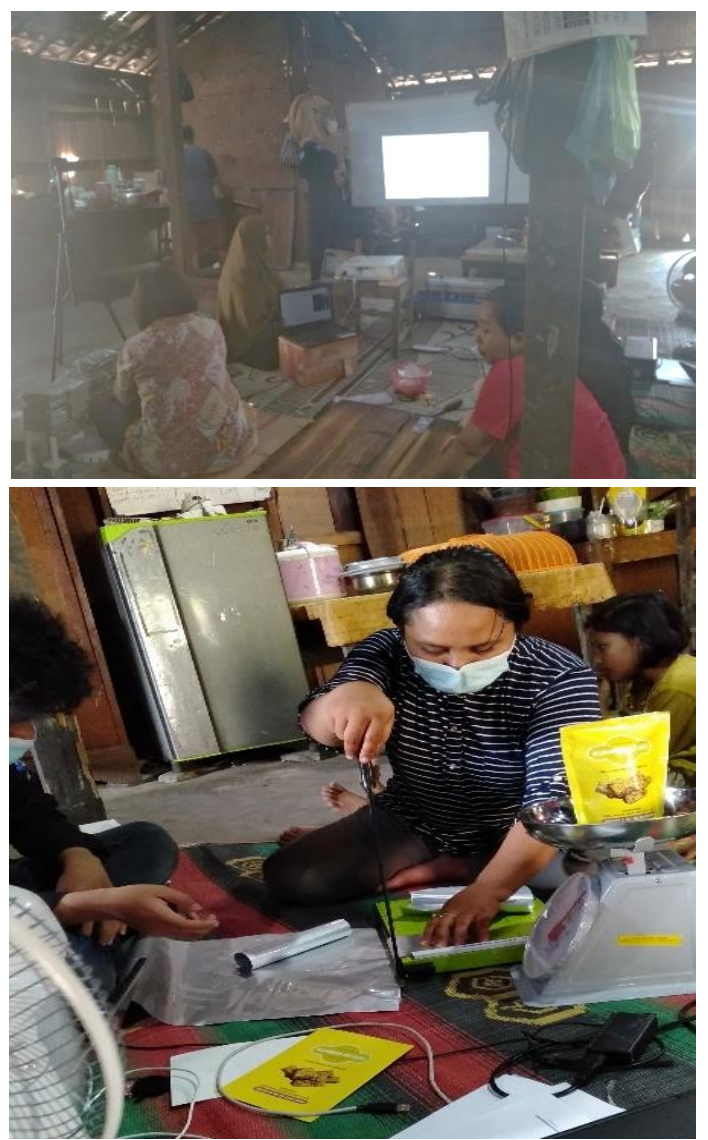

Gambar 4. Pelatihan Pengemasan Produk

Materi yang diberikan juga terkait bagaimana memilih kemasan yang sesuai dengan produk dan pasar. Bahar dan Sjahruddin (2017:16) menyatakan bahwa dalam kondisi persaingan yang ketat, hal utama yang harus diprioritaskan adalah kepuasan pelanggan (customer satisfaction) yang pada akhirnya akan menarik minat pelanggan untuk membeli ulang suatu produk, sehingga perusahaan dapat bertahan, bersaing dan menguasai pangsa pasar. Sementara itu, minat beli ulang suatu produk dipengaruhi langsung oleh kepuasan pelanggan pada merek yang diakumulasikan melalui waktu. Jika pelanggan puas terhadap kualitas produk atau layanan yang diberikan maka akan cenderung membeli ulang. Begitu juga pada produk makanan tradisional, di 
Pemberian alat pengemasan dan pelatihan peningkatan kualitas makanan khas geti di .........

mana kualitas produk baik rasa dan tampilan sangat mempengaruhi penjualan.

Kualitas produk adalah keseluruhan kualitas atau keunggulan suatu produk atau jasa layanan berkaitan dengan apa yang diharapkan oleh pelanggan. Kualitas adalah totalitas fitur dan karakteristik yang memampukan produk memuaskan kebutuhan yang dinyatakan maupun tidak dinyatakan (Lasander, 2013:285). Salah satu kualitas dapat dilihat dari kemasan produk.

Noviadji (2014:13) menyatakan bahwa pada zaman modern seperti saat ini desain kemasan yang dipergunakan produsen bahan pangan diklasifikasikan dalam beberapa kelompok. Kelompokkelompok tersebut diantaranya 1). Berdasarkan frekuensi pemakaian (Kemasan sekali pakai, kemasan yang dapat dipakai berulang kali), 2) berdasarkan struktur sistem kemas, 3.) Berdasarkan sifat kekakuan bahan kemasan, dan 4) berdasarkan sifat perlindungan terhadap lingkungan.

Beberapa peranan umum dari kemasan makanan adalah mempertahankan bahan dalam keadaan bersih dan higienis, mengurangi terbuangnya bahan selama distribusi, mempertahankan gizi produk yang dikemas, hingga sebagai alat penakar, media informasi dan sekaligus sebagai sarana promosi. Untuk mendukung peranan tersebut, maka perlu melakukan pendesainan kemasan. Tujuannya adalah menampilkan atribut unik sebuah produk untuk menjadi pembeda dengan produk lain untuk menarik perhatian, memperkuat penampilan estetika dan nilai produk, mempertahankan keseragaman dalam kesatuan merek produk, atau menggunakan material baru dan mengembangkan struktur inovatif untuk mengurangi biaya, lebih ramah lingkungan, atau meningkatkan fungsionalitas.

Tim juga melakukan evaluasi setelah kegiatan selesai. Evaluasi pertama melalui pre test dan post test, yaitu peserta menjawab pertanyaan-pertanyaan tentang materi pelatihan pada sebelum pelatihan dan setelah pelatihan. Hasil analisis menunjukkan bahwa hanya $28 \%$ peserta yang menjawab dengan benar sebelum pelatihan. Sementara itu, terdapat $92 \%$ peserta yang mampu menjawab dengan benar setelah pelatihan. Hal ini menunjukkan bahwa materi pelatihan dapat dipahami dengan baik oleh peserta.

Evaluasi kedua adalah dengan membagikan kuesioner tentang tingkat kepuasan. Hasil pada Tabel 1 menunjukkan bahwa peserta menyatakan sangat puas terhadap pelaksanaan pelatihan. Hal ini ditunjukkan oleh penilaian tingkat kepuasan baik dari isi materi, pemateri, maupun suasana pelatihan.

Tabel 1. Tingkat kepuasan terhadap

\begin{tabular}{|l|c|}
\multicolumn{1}{c}{ pelatihan } \\
\hline \multicolumn{1}{|c|}{ Hal } & $\begin{array}{c}\text { Tingkat } \\
\text { kepuasan }(0- \\
100)\end{array}$ \\
\hline $\begin{array}{l}\text { Tingkat kepuasan terhadap } \\
\text { isi materi }\end{array}$ & 92.5 \\
\hline $\begin{array}{l}\text { Tingkat kepuasan terhadap } \\
\text { pemateri }\end{array}$ & 96.7 \\
\hline $\begin{array}{l}\text { Tingkat kepuasan terhadap } \\
\text { suasana pelatihan }\end{array}$ & 95.0 \\
\hline
\end{tabular}


Selain menyatakan tingkat kepuasan seperti pada Tabel 1, peserta juga menyampaikan masukan yaitu, pelatihan terkait penggunaan alat pengemasan dan pemanfaatan sosial media juga dilakukan ke UMKM lain sehingga kualitas produk UMKM di Desa Wonosari dapat lebih bersaing. Dengan demikian, walaupun menyatakan telah puas dalam pelatihan yang telah diberikan, mereka masih membutuhkan jenis-jenis pelatihan lain.

\section{SIMPULAN}

Dari program yang diberikan kepada mitra, pelaku usaha Geti Bu Atmo, didapatkan kesimpulan bahwa pemberian bantuan alat pengemasan produk dan pelatihan penggunaannya telah memberikan banyak manfaat. Mitra dapat membuat kemasan geti yang lebih menarik dan bersaing di pasar. Selanjutnya diharapkan tingkat penjualan semakin meningkat.

Keberhasilan pelatihan juga dilihat dari hasil perbandingan pre test dan post test serta tingkat kepuasannya. Sejumlah 92\% peserta yang mampu menjawab dengan benar setelah pelatihan. Peserta juga menyatakan sangat puas terhadap pelaksanaan pelatihan baik dari isi materi, pemateri, maupun suasana pelatihan

\section{UCAPAN TERIMAKASIH}

Kegiatan pengabdian ini adalah rangkaian dari kegiatan PHP2D dan KKNT MBKM. Tim mengucapkan terimakasih kepada Direktorat Pembelajaran dan Kemahasiswaan, Direktorat Jenderal Pendidikan Tinggi, Kementerian Pendidikan dan Kebudayaan yang telah memberikan dana hibah PHP2D Tahun 2021 kepada tim HIMASTA IST AKPRIND Yogyakarta, serta memberikan dana program KSKI Merdeka Belajar Kampus Merdeka (MBKM) kepada tim Jurusan Statistika IST AKPRIND Yogyakarta Tahun 2021.

\section{DAFTAR PUSTAKA}

A'Yunin, F. (2018). Analisis strategi pemasaran produk halal dalam upaya menjaga loyalitas konsumen (Studi Kasus Pada Perusahaan Kue Geti UD Primadona Tulungagung).

Bahar, A., \& Sjahruddin, H. (2017). Pengaruh Kualitas produk dan kualitas pelayanan terhadap kepuasan konsumen dan minat beli ulang.

Bekti, R. D., Suryowati, K., \& Suseno, H. P. (2020a). Pemberian Sosialisasi dan Bantuan Pencegahan Covid-19 bagi Warga Malangan Kota Yogyakarta Berdasarkan Analisis Tingkat Pengetahuan. Abdimasku: Jurnal Pengabdian Masyarakat, 3(3), 99-105.

Bekti, R. D., Suryowati, K., \& Suseno, H. P. (2020b). Program penanaman sayuran bagi warga RT 37 Malangan, Kota Yogyakarta sebagai upaya penghijauan dan mendukung ekonomi. Jurnal Abdimas Siliwangi, 3(2), 310-318.

Lasander, C. (2013). Citra merek, kualitas produk, dan promosi pengaruhnya terhadap kepuasan konsumen pada makanan tradisional. Jurnal EMBA: Jurnal Riset Ekonomi, Manajemen, Bisnis dan Akuntansi, 1(3).

Noviadji, B. R. J. A. (2014). Desain kemasan tradisional dalam konteks kekinian. 1(1), 10-21. 
Rachmawati, I. D. (2018). Konsep Cara Produksi Pangan yang Baik (Cppb) pada Pembuatan Geti Wijen di Ukm "Pak Kino" Geneng, Purwosari, Wonogiri.

Sunarsasi, S., \& Hartono, N. R. (2020). Strategi pemasaran usaha kecil menengah di Kabupaten Blitar. Translitera: Jurnal Kajian Komunikasi Dan Studi Media, 9(1), 22-31.

Suprayitno, H., Lukito, R., \& Farida, N. (2021). Rekonstruksi dampak ekonomi UMKM Kabupaten Blitar di tengah covid-19. JAAKFE UNTAN, 10(1), 44-52.

Suryowati, K., Suseno, H. P., \& Bekti, R. D. (2020). Program pengelolaan sampah bagi warga Rt 37 Malangan, Kota Yogyakarta untuk mewujudkan lingkungan yang sehat. Seminar Nasional Hasil Penelitian dan Pengabdian Masyarakat.

Triachdiani, N., \& Murtini, E. S. (2021). Pengaruh varietas kacang tanah (Arachis Hypogaea 1.) dan rasio gula aren: Gula pasir terhadap karakteristik enting-enting geti. Jurnal Pangan dan Agroindustri, 9(2), 100-110. 